\title{
CORRIGENDUM
}

\section{Genome-wide common and rare variant analysis provides novel insights into clozapine-associated neutropenia}

SE Legge, ML Hamshere, S Ripke, AF Pardinas, Jl Goldstein, E Rees, AL Richards, G Leonenko, LF Jorskog, Clozapine-Induced Agranulocytosis Consortium, KD Chambert, DA Collier, G Genovese, I Giegling, P Holmans, A Jonasdottir, G Kirov, SA McCarroll, JH MacCabe, K Mantripragada, JL Moran, BM Neale, H Stefansson, D Rujescu, MJ Daly, PF Sullivan, MJ Owen, MC O'Donovan and JTR Walters

Molecular Psychiatry (2017) 22, 1509; doi:10.1038/mp.2016.137; published online 9 August 2016

Correction to: Molecular Psychiatry advance online publication, 12 July 2016; doi:10.1038/mp.2016.97

The ninth author's name was presented incorrectly. It should have been listed as LF Jarskog. (c) (i) This work is licensed under a Creative Commons Attribution 4.0 International License. The images or other third party material in this article are included in the article's Creative Commons license, unless indicated otherwise in the credit line; if the material is not included under the Creative Commons license, users will need to obtain permission from the license holder to reproduce the material. To view a copy of this license, visit http://creativecommons.org/licenses/ by/4.0/

(c) The Author(s) 2017 